\title{
Cliff collapse at Stevns Klint, south-east Denmark
}

\author{
Stig A. Schack Pedersen and Tove Damholt
}

The scenic coastal cliff of Stevns Klint is a classical study locality that stretches for $15 \mathrm{~km}$ along the east coast of Sjælland and it holds arguably the best exposed Cretaceous-Tertiary boundary in the world (Fig. 1; Damholt \& Surlyk 2012). The famous boundary separates the soft Cretaceous chalk from the harder overlying Tertiary bryozoan limestone (Fig. 2), and the difference between the two rock types controls the character of the frequent cliff falls. The relatively soft chalk at the base is eroded by storm waves and is subject to general debris shedding. The overlying bryozoan limestone, with its hardgrounds and flint layers, is more resistant to erosion and is strong enough to form overhanging projections of the coastal cliff that result in large and small recurring collapses.

The position of the Cretaceous-Tertiary boundary varies in altitude along the cliff from about $5 \mathrm{~m}$ below sea level in the southern part of the cliff to $c .35 \mathrm{~m}$ above sea level in the northern part. Hence the southern part of the cliff mainly consists of hard bryozoan limestone whereas the central and northern parts consist of soft chalk overlain by bryozoan limestone. Throughout the entire length of the cliff the carbonate rock is overlain by a few metres of glacial till.

Stevns Klint has recently been proposed for inclusion on the World Heritage Site List (Damholt \& Surlyk 2012) and as part of the nomination process a risk assessment of the frequency of cliff collapse was conducted. This paper describes

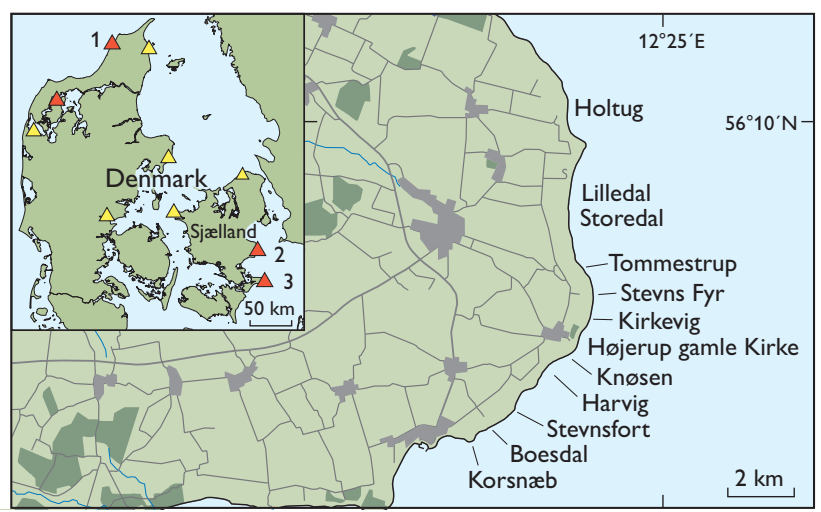

Fig. 1. Map of the Stevns Klint region showing place names mentioned in the text. The inset map shows the distribution of localities with major landslides in Denmark. Red trinangles: the most hazardous slides. Yellow triangles: clayey landslides. 1: Lønstrup Klint, 2: Stevns Klint, 3: Møns Klint. the analysis of erosion and rockfall that formed the background of the risk assessment.

\section{Cliff-collapse analysis of Stevns Klint}

The evaluation of the cliff-collapse risk at Stevns Klint included an analysis of the size and character of the present overhang, the vulnerability of the cliff to erosion and rockfall dimensions. The analysis was based on a photogrammetric investigation using a series of oblique photographs taken in April 2011. The cliff section was mapped in segments and detailed photogrammetric measurements were made using the software SocketSet in the photogrammetric laboratory at the Geological Survey of Denmark and Greenland. The result was stored in a GIS database using the ArcGis format (Pedersen \& Strunck 2011).

Results from a previous photogrammetric investigation using oblique photographs taken in 1992 (Surlyk et al. 2006) were compared with our results to describe the changes in the cliff profile over the past 20 years. The general conditions of cliff erosion are described and the rockfall dynamics for the various types of cliff collapse are characterised.

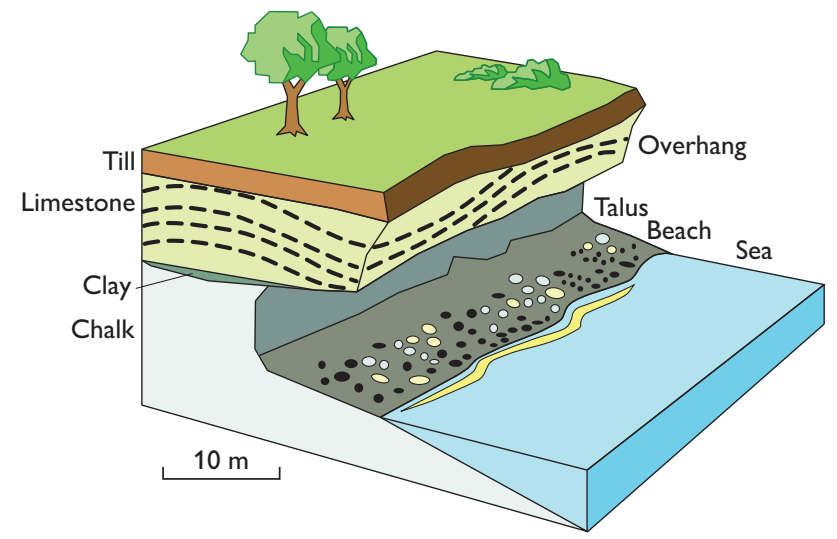

Fig. 2. Block diagram illustrating the morphology and rock types present in the Stevns Klint exposures. The succession consists of Maastrichtian chalkish clay, with the famous Cretaceous-Tertiary boundary at the base, Danian bryozoan limestone and Weichselian glacial till. 


\section{General erosion conditions at Stevns Klint}

The rate of erosion is an essential factor for the assessment of cliff collapse. We estimated the average rate of coastal erosion at Stevns Klint to be $15 \mathrm{~cm} /$ year, based on comparisons of the position of the coastline in 1891 with that in 2010, provided by the National Survey and Cadastre. The highest rate $(c .35 \mathrm{~cm} /$ year $)$ was found in the northern part of the cliff between Storedal and Lilledal (Fig. 1). In some places, progradation of the coastline occurs where beach ridges form or where old cliff slides act as wave breakers. Beach ridges are especially found at Korsnæb in the south (Fig. 1), where the accumulation rate amounts to $12 \mathrm{~cm} /$ year. A landslide north of Kirkevig and south of Storedal (Fig. 1) has resulted in a coastline progradation of $7-9 \mathrm{~cm} /$ year.

Limestone quarrying over the past few hundred years has also altered the cliff profile. Numerous small quarries were established directly on the cliff with quarry walls inclined towards the base of the limestone and resulted in considerable overhang. The quarries can contribute to cliff points projecting above the beach.
The erosion rate at Stevns Klint is modest when compared with the highest rate of coastal erosion in Denmark, which is $1.25 \mathrm{~m} /$ year at Lønstrup Klint that is formed in Quaternary sediments (Fig. 1; Pedersen 1986).

\section{Types of cliff collapses at Stevns Klint}

The largest type of cliff collapse at Stevns Klint can be called cliff slides (Fig. 3). This type of slide includes a major part of the cliff for several tens of metres along the coastline which slide simultaneously. In general a cliff slide takes place along a steeply dipping surface and it involves a volume of 5000 to $10000 \mathrm{~m}^{3}$. Prior to a cliff-slide a whole section of the chalk has been eroded away at sea level, creating an undercut below the limestone and resulting in a considerable overhang. The size of the overhang has to be around $10-12 \mathrm{~m}$ and the thickness of the limestone and till in the overhang around $15-18 \mathrm{~m}$ before it becomes unstable.

The most famous event at Stevns Klint occurred in 1928, when a large cliff slide dramatically tore away the choir of
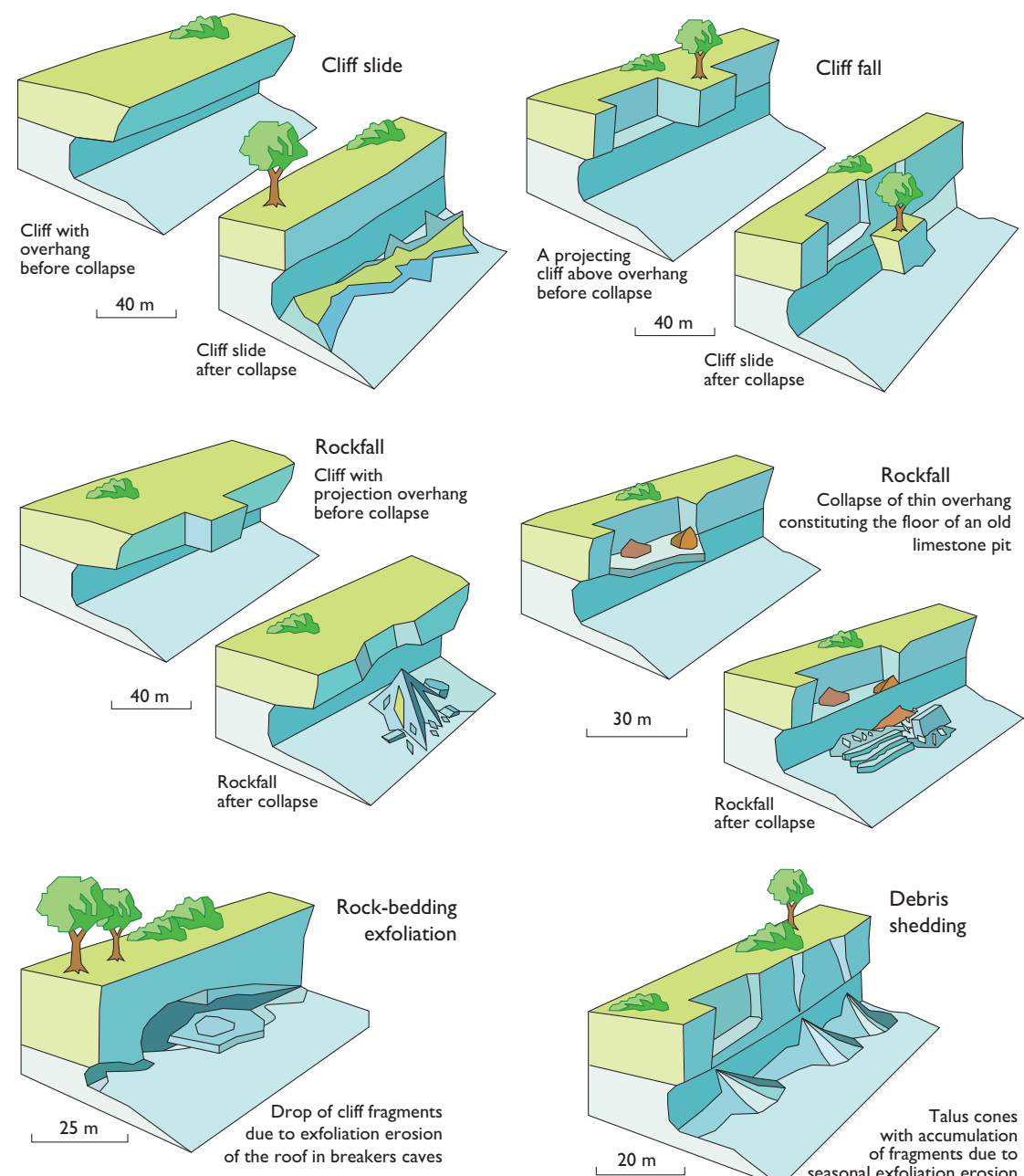

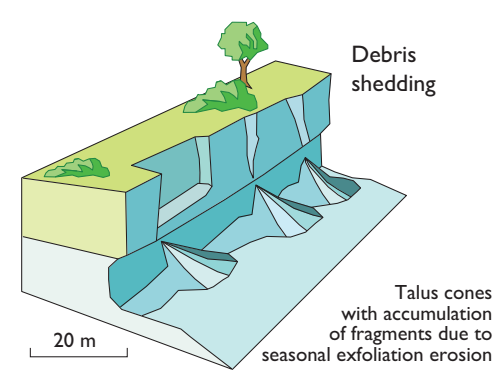

Fig. 3. Cliff-collapse types at Stevns Klint. The most hazardous type is the cliff slide involving volumes of 5000-10 $000 \mathrm{~m}^{3}$. The volume of a cliff fall amounts only to $500-1500 \mathrm{~m}^{3}$, but still a cliff fall is an impressive sight with the bedding completely preserved in a displaced cliff fragment. The rockfall is the general type of cliff collapse and is illustrated by two examples, of which the plate-like overhang corresponds to a recent cliff collapse at Knøsen. The rock-bedding exfoliation generates platy $1-10 \mathrm{~m}^{3}$ limestone blocks, which drop from the underside of the overhang. The main erosion of the cliff is caused by debris shedding, which produces the talus at the foot of the cliff. 


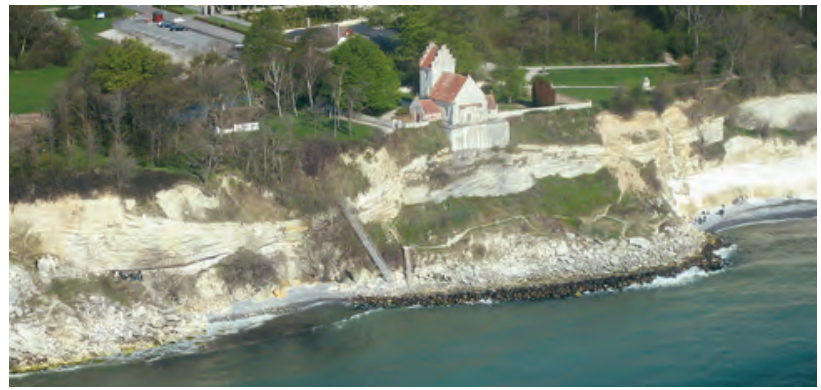

Fig. 4. Aerial photograph of the cliff section at Højerup gamle Kirke (medieval church).

Højerup gamle Kirke (a medieval church) that rested on a $15 \mathrm{~m}$ thick overhang. The slide continued several tens of metres out into the sea (Fig. 4). Shortly after the incident the cliff was protected by wave breakers to inhibit wave erosion and to secure the rest of the old church. Prior to the spectacular slide, the undercutting erosion had lasted for 160 years following an earlier slide in 1767 (Rasmussen 1967). Before the cliff collapse in 1928, the overhang amounted to $c .12 \mathrm{~m}$ measured perpendicularly to the orientation of the cliff and a similar overhang size is estimated for the collapse in 1767. An overhang of $c .12 \mathrm{~m}$ is thus regarded as a critical size for cliff slides where the overhang thickness is $c .15 \mathrm{~m}$.

A significant cliff slide has occurred at Tommestrup (Figs $1,5 \mathrm{~A})$ and another one in the inner part of Harvig. At both sites cliff-slide deposits will protect the cliff from erosion for the next decades.

In order of decreasing size, the next type of large collapse is the cliff fall (Fig. 3). Cliff falls only involve isolated projecting parts of the cliff with a considerable overhang and their volumes are $500-1500 \mathrm{~m}^{3}$. The cliff fall is a simple drop of part of the cliff where the bedding of the fallen block is preserved after the fall. The average relation between thickness and depth of the overhanging limestone prior to cliff fall is 3 to 2 as illustrated in the cliff fall below the lighthouse of Stevns Fyr (Figs 1, 5B).

The third type of collapse is classified as rockfalls (Fig. 3), which in this analysis varies in size from 1 to $500 \mathrm{~m}^{3}$. This type may occur together with block slides, in which bigger blocks are displaced together with finer-grained material such as clayey till and sand. The resulting aggradation of material on the shore after a rockfall is a chaotic breccia. In general, rockfalls leave a concave escarpment in the cliff and the aggradation of debris results in a cone expanding out into the sea.

Platy rockfall, caused by rock-bedding exfoliation, involves rock volumes of around $1 \mathrm{~m}^{3}$ and is a significant type of collapse at Stevns Klint (Fig. 3). Rock-bedding exfoliation occurs in caves eroded by storm waves in the lower part of the cliff. Layers are peeled off from the roofs of the cave due to exfoliation, and dish-shaped fragments of rock drop to the cave floor. Caves are prominent north of Boesdal (Fig. 1) and
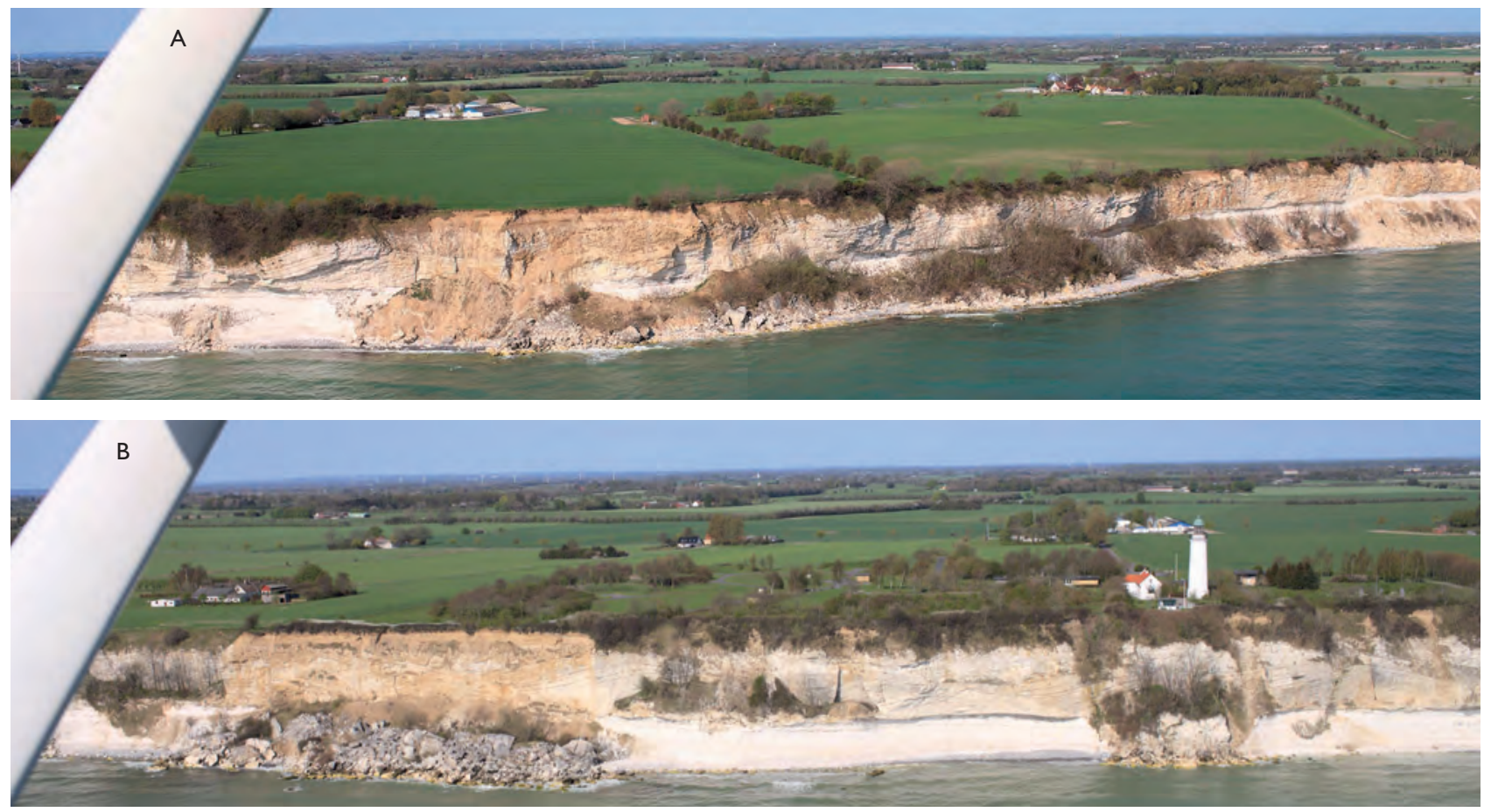

Fig. 5. Cliff sections showing various types of rockfalls at Stevns Klint. A: Cliff slide at Tommestrup. B: Cliff fall at the lighthouse of Stevns Fyr. 


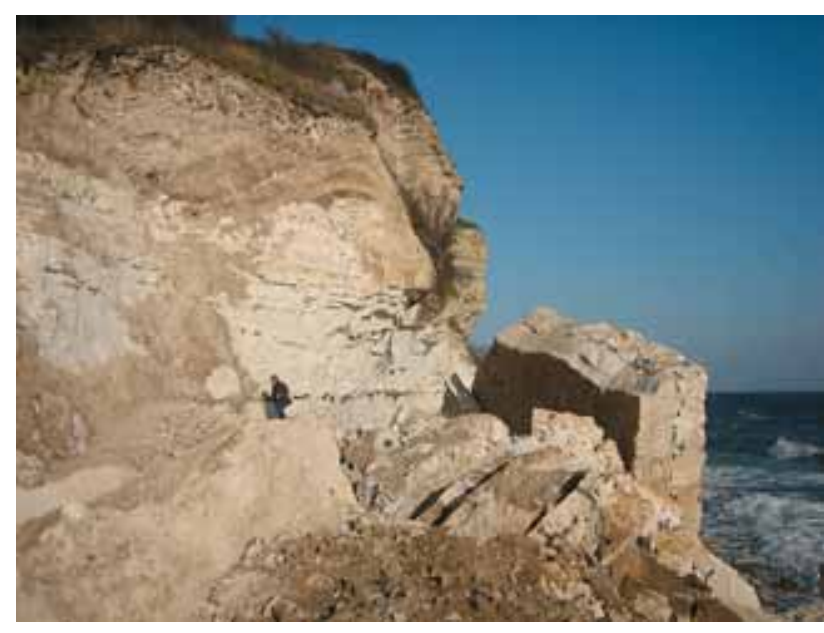

Fig. 6. The cliff collapse at Knøsen, which occurred in November 2011. The weight of fill deposited on top of the section added to the load of the overhang.

north of Stevnsfort where they are formed in limestone and extend up to $9 \mathrm{~m}$ into the cliff. Caves formed in chalk occur south of Storedal and at Holtug.

Finally, fragments of rock may fall from the cliff due to general shedding of debris (Fig. 3). In general, the material resulting from debris shedding is pebbles and cobbles, whereas clasts of boulder-size are loosened only occasionally from the cliff surface. The result is seen as an apron of talus along the foot of the cliff, typically with irregular conical shapes. Debris shedding results from contraction and expansion due to seasonal variation of frost and thaw in winter time and desiccation during the summer. The rate of erosion due to debris shedding is equal to the average rate of erosion, i.e. $15 \mathrm{~cm} /$ year.

\section{Assessment of cliff collapse hazards at Stevns Klint}

The size of the overhang is considered to be the most important factor in the assessment analysis of rockfall hazards at Stevns Klint. However, the likelihood of a collapse also depends on the thickness of the overhang. The shear strength of a rock increases with increasing normal pressure, which increases with the thickness of the rock. Therefore an overhang with a thickness of $20 \mathrm{~m}$ is more stable than one with a thickness of $10 \mathrm{~m}$. The degree of exposure to the sea is also important, primarily because the exposed parts of the cliff are affected by wave erosion and secondly because the softness of chalk increases by salt water spray (Mortimore $e t a l$.
2004). Finally, the assessment of risk is proportional to the number of visitors. A more detailed description of the assessment is provided in a full report (Pedersen \& Strunck 2011).

After our analysis, a rockfall of $c .300 \mathrm{~m}^{3}$ occurred at Knøsen (Fig. 1). The rockfall was discovered on 6 November 2011. It was caused by the collapse of a $5 \mathrm{~m}$ overhang with a thickness of $2 \mathrm{~m}$ that constituted the floor of an old limestone quarry (Figs 3, 6). The floor carried the weight of removed overburden, in the form of clayey till and chertrich limestone rubble. The collapse shows that an overhang with a thickness of just $2 \mathrm{~m}$ can become unstable even if the overhang is only $5 \mathrm{~m}$. In other instances an overhang with a thickness of $15 \mathrm{~m}$ can be stable even with an undercut of more than $10 \mathrm{~m}$.

\section{Discussion and conclusions}

Our cliff-collapse hazard assessment of Stevns Klint is based on an investigation of cliff collapse processes along the cliff. Five types of cliff collapse are recognised: cliff slides, cliff fall, rockfall, platy rockfall caused by rock-bedding exfoliation and debris shedding. The cliff slides have large volumes and occur at low frequencies ( $1 / 100$ years) whereas debris shedding of low volume occurs at high frequencies (seasonal). The resulting average rate of erosion is $15 \mathrm{~cm} /$ year. Rockfalls may be initiated by cycles of frost and thaw, saturation of cracks following rainy periods or desiccation after dry periods, but actual prediction of cliff collapses is not possible at present.

\section{References}

Damholt, T. \& Surlyk, F. 2012: Nomination of Stevns Klint for inclusion in the World Heritage List, 159 pp. St. Heddinge: Østsjællands Museum.

Mortimore, R.N., Stone, K.J., Lawrence, J. \& Duperret, A. 2004: Chalk physical properties and cliff stability. In: Mortimore, R.N. \& Duperret (eds): Coastal chalk cliff instability. Geological Society (London), Engineering Geology Special Publications 20, 75-88.

Pedersen, S.A.S. 1986: Rubjerg klint, Rubjerg klit, årsag og virkning. Varv 3, 84-98.

Pedersen, S.A.S. \& Strunck, M.N. 2011: Vurdering af fjeldskredsrisiko på Stevns Klint. Danmarks og Grønlands Geologiske Undersøgelse Rapport 2011/93, $100 \mathrm{pp}$.

Rasmussen, H.W. 1967: Skrivekridtet og kalkstenene. In: Nørvang, A. \& Meyer, T.J. (eds): Danmarks Natur 1, Landskabets opståen, 131-160. Copenhagen: Politikens Forlag.

Surlyk, F., Damholt, T. \& Bjerager, M. 2006: Stevns Klint: Uppermost Maastrichtian chalk, Cretaceous-Tertiary boundary, and lower Danian bryozoan mound complex. Bulletin of the Geological Society of Denmark 54, 1-48.

\footnotetext{
Authors' addresses

S.A.S.P., Geological Survey of Denmark and Greenland, ØsterVoldgade 10,DK-1350 Copenhagen K, Denmark. E-mail: sasp@geus.dk T.D., Østsjellands Museum, Højerup Bygade 38, DK-4660 St. Heddinge, Denmark.
} 